
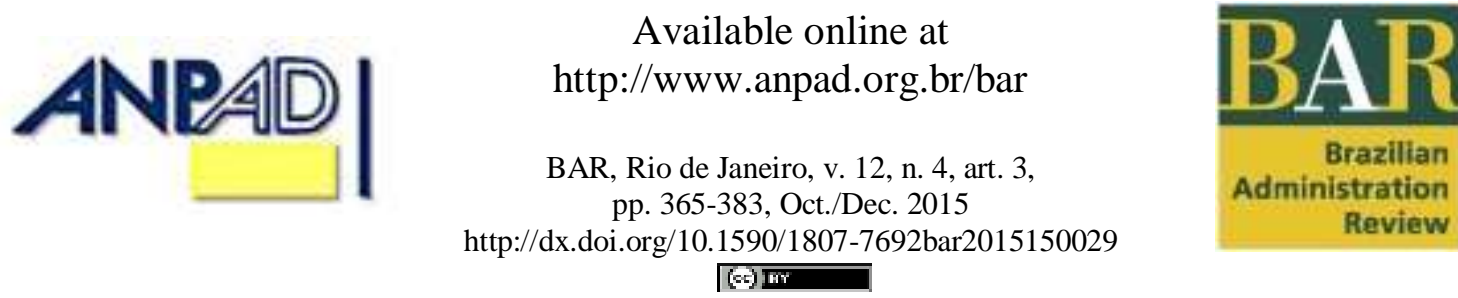

$(\mathrm{ec})$

\title{
Organizing for Ambidexterity: A Paradox-based Typology of Ambidexterity-related Organizational States
}




\begin{abstract}
This paper addresses the question of how organizations become ambidextrous over time, identifying requirements for organizations to become ambidextrous, understanding how ambidexterity may emerge as an organizational property, as well as exploring likely connections of the ambidexterity property and organizing a firm's activities and work. Conceptualizing the exploration-exploitation relationship as a paradoxical one, we advance two necessary conditions for organizing for ambidexterity: fostering paradox-coping tactics and precluding paradoxrelated traps. The interplay of these two conditions gives rise to a typology of four ambidexterity-related organizational states: ambidexterity-lacking organizations, monolithic organizations, short-term ambidextrous organizations and long-term ambidextrous organizations. The paper identifies each state's distinct strengths and challenges concerning organizing for ambidexterity, and discusses theoretical, practical and policy-making implications.
\end{abstract}

Key words: organizational ambidexterity; paradox; growth; exploitation; exploration. 


\section{Introduction}

Organizational ambidexterity has received a lot of attention in strategic management literature. The number of studies on this topic in leading management journals has steadily increased over time, constituting one of the most enduring ideas in organization sciences (Raisch, Birkinshaw, Probst, \& Tushman, 2009). The construct's core proposition states that an organization's success hinges on its ability to exploit its current capabilities while simultaneously exploring fundamental new competencies (Levinthal \& March, 1993; March, 1991). Moreover, the construct is potentially relevant to explain why empirical data shows that only a few organizations have been successful in balancing contradictory pressures of short-term profits and long-term survival (Aldrich \& Rueff, 1999; Coad, 2009; Coad \& Tamvada, 2008; Feser, 2012; O’Reilly, Harreld, \& Tushman, 2009; Simonetti, 1996; Stubart \& Knight, 2006). The expanding literature on the construct offers a lot of common ground for researchers. However, it still includes open questions that call for further research.

For instance, there is a lot of common ground concerning what organizational ambidexterity is. Generally understood as the catalyst for the current interest in the construct (Raisch \& Birkinshaw, 2008), March's (1991) landmark paper essentially proposed that exploitation and exploration are two fundamentally different types of activities which firms divide their attention and resources between. Actually, literature on the topic builds on March's (1991) seminal notion that organizational ambidexterity is defined by a firm's ability to effectively balance both exploration (such as refinement, efficiency, selection and implementation) and exploitation (such as search, variation, experimentation and discovery).

Also, it is widely accepted that the reason why firms should become ambidextrous has to do with the connection between organizational ambidexterity and long-term success. Although studies have pointed out the need to clarify this link through longitudinal efforts (Cao, Gedajlovic, \& Zhang, 2009; Simsek, 2009) in order to avoid tautological claims often associated with the resource-based view (Priem \& Butler, 2001; Williamson, 1999; Winter, 2003; Zott, 2003), the assertion that organizational ambidexterity contributes to a firm's healthy longevity is hardly challenged. Moreover, large-scale empirical studies have complemented conceptual work providing evidence of organizational ambidexterity's general association with performance (Gibson \& Birkinshaw, 2004; He \& Wong, 2004; Lubatkin, Simsek, Ling, \& Veiga, 2006).

However, there still are open questions demanding further research. These include issues associated with how organizations become ambidextrous, such as identifying the likely requirements for organizations to become ambidextrous and understanding how ambidexterity may emerge as an organizational property, as well as exploring likely connections of the ambidexterity property and organizing a firm's activities and work.

Even though several studies have provided piecemeal examples (O'Reilly \& Tushman, 2011) or tackled ambidexterity's emergence in specific situations, such as in new product development efforts (Andriopoulos \& Lewis, 2009; Chang, Hughes, \& Hotho, 2011), the field still lacks a comprehensive understanding of how organizations foster and sustain ambidexterity as an organizational property. Perhaps Gupta, Smith and Shalley (2006, p. 697) put it best when they noted that, "although near consensus exists on the need for balance of exploitation and exploration, there is considerably less clarity on how this balance can be achieved". Research to date has typically employed only one variable to explain organizational ambidexterity, such as dual structures (Benner \& Tushman, 2003), behavioural context (Gibson \& Birkinshaw, 2004), or top management team (TMT) behavioural integration (Lubatkin et al., 2006). Lacking integrative models spanning multiple levels of analysis (Gupta, Smith, \& Shalley, 2006), previous studies thus far 'have not generated an overarching theory' to explain organizational ambidexterity (Simsek, 2009).

Aiming at contributing understanding on how organizations become ambidextrous over time, we have scrutinized the nature of the ambidexterity construct, identified two requirements for organizations to become ambidextrous, and explored issues related to organizing for ambidexterity. We propose two 
necessary conditions for developing ambidexterity: fostering paradox-coping tactics as well as precluding paradox-related traps. The interplay of these two conditions gives rise to a typology of four ambidexterity-related states, entailing distinct organizing features.

The envisaged contribution includes three main aspects. First, we suggest that the paradox notion properly addresses the distinct characteristics of the tension-like relationship between exploration and exploitation (namely its mutual complementarities and opposition). Second, we identify two necessary conditions for fostering and sustaining organizational ambidexterity: employing paradox-coping tactics and avoiding specific paradox-related traps. Third, we derive four different organizational states, whose formation depends on how the necessary conditions are addressed. A four-state typology organizes these states, whose strengths and deficiencies vis-à-vis organizing for ambidexterity differ among states.

\section{Investigating the Nature of the Tension between Exploration and Exploitation}

Tensions such as the one shown in the organizational ambidexterity construct (between exploration and exploitation) are not new in the strategic management field. At the heart of several strategic issues, a fundamental tension between apparent opposites can be identified (DeWit \& Meyer, 2010). These tensions span multiple analytical levels and cannot be eliminated because they are inherent to the very subject matter (Dougherty \& Hardy, 1996). Selected examples in Table 1 illustrate some of the tensions that can be identified in the strategic management literature.

Table 1

Selected Examples of Tensions that Have Been Historically Treated within the Strategic Management Field

\begin{tabular}{|c|c|c|c|c|}
\hline THEME & $\begin{array}{l}\text { ANALYTICAL } \\
\text { LEVEL }\end{array}$ & EXEMPLIFIED TENSION & $\begin{array}{l}\text { CONCEPTUAL } \\
\text { PERSPECTIVES }\end{array}$ & $\begin{array}{l}\text { SELECTED } \\
\text { REFERENCE }\end{array}$ \\
\hline \multirow{2}{*}{$\begin{array}{l}\text { Strategy } \\
\text { Process }\end{array}$} & Strategy Formation & Deliberate $\longleftrightarrow$ Emergent & $\begin{array}{l}\text { Strategic Planning vs } \\
\text { Strategic Incrementalism }\end{array}$ & $\begin{array}{l}\text { Mintzberg and } \\
\text { Waters (1985) }\end{array}$ \\
\hline & Strategic Chance & Revolution $\longleftrightarrow$ Evolution & $\begin{array}{l}\text { Discontinuous Renewal } \\
\text { vs Continuous Renewal }\end{array}$ & $\begin{array}{l}\text { Christensen and } \\
\text { Raynor (2013) }\end{array}$ \\
\hline \multirow{4}{*}{$\begin{array}{l}\text { Strategy } \\
\text { Content }\end{array}$} & \multirow{2}{*}{ Firm Level } & Explore $\longleftrightarrow$ Exploit & $\begin{array}{l}\text { Organizational } \\
\text { Ambidexterity }\end{array}$ & March (1991) \\
\hline & & Commitment $\longleftrightarrow$ Flexibility & $\begin{array}{c}\text { Path Dependence, } \\
\text { Strategy As Real Options }\end{array}$ & $\begin{array}{l}\text { Ghemawat } \\
\text { (1991) }\end{array}$ \\
\hline & \multirow[b]{2}{*}{ Industry Level } & Competition $\longleftrightarrow$ Collaboration & $\begin{array}{l}\text { Discrete Organization vs } \\
\text { Embedded Organization }\end{array}$ & $\begin{array}{l}\text { Brandenburger } \\
\text { and Nablebuff } \\
\text { (1995) }\end{array}$ \\
\hline & & Heterogeneity $\longleftrightarrow$ Isomorsphism & $\begin{array}{l}\text { Resource-Based View vs } \\
\text { Institutionalism }\end{array}$ & $\begin{array}{l}\text { Peteraf (2003), } \\
\text { Dimaggio and } \\
\text { Powell (1983) }\end{array}$ \\
\hline $\begin{array}{l}\text { Strategy } \\
\text { Purpose }\end{array}$ & $\begin{array}{l}\text { Organizational } \\
\text { Purpose }\end{array}$ & Optimization $\longleftrightarrow$ Satisfaction & $\begin{array}{l}\text { Shareholder Value vs } \\
\text { Stakeholder Value }\end{array}$ & Doyle (1994) \\
\hline
\end{tabular}

Note. Source: Adapted from DeWit, B., \& Meyer, R. (2010). Strategy: process, content, context - an international perspective (p. 13). Boston: Cengage Learning.

Concerning the strategy process, a well-known tension-like relationship refers to deliberate, topdown strategic planning and emergent, bottom-up strategy formation (Mintzberg \& Waters, 1985). Another common tension in the literature regards continuous, incremental, piecemeal renewal and discontinuous, disruptive innovations and technological change renewal (Christensen \& Raynor, 2013). 
Tensions regarding strategy content include the very tension that lies ate the heart of the organizational ambidexterity construct; i.e. between exploration of current capabilities and the exploration of new ones (March, 1991). Another firm level tension - commitment to specific choices and the value of flexibility (Ghemawat, 1991) - touches upon path dependence in strategizing.

At the industry level, a widely known tension concerns the degree of competition and collaboration within an industry (Brandenburger \& Nablebuff, 1995). Another one pertains to the behavior of firms in a focal industry, which may emphasize compliance with industry standards and best practices (thus producing isomorphism among companies) or choosing to strive for uniqueness (producing heterogeneity). The isomorphism-heterogeneity tension nurtures the debate between two conceptual perspectives: the resource-based view (Barney, 1991; Peteraf, 2003) and institutionalism (DiMaggio \& Powell, 1983).

As for strategy purpose, the discussion concerning top management duties -maximizing shareholders value or satisfying stakeholders needs (Doyle, 1994) - illustrates organizational purposerelated tensions.

Over time, the above mentioned tensions have developed into different fields of study that embrace multiple conceptual perspectives. Moreover, they do not share one single conceptual nature, as the relationship between the opposing poles may have distinct characteristics.

\section{Possible conceptualizations of tensions within Strategic Management}

The relationship between opposing poles within a given strategic tension may be conceptualized in several ways: as trade-offs, puzzles, dilemmas and paradoxes. Each conceptualization offers different perspectives on the nature of the relationship between the poles, bringing about implications regarding the way organizations must cope with each tension.

Qualifying a tension as trade-off implies the occurrence of numerous different combinations between two apparent opposites, none of which is inherently superior to all others (DeWit \& Meyer, 2010). The tension between responsiveness and synergy in multi-business firms could be characterized as a trade-off: when organizations navigate through highly uncertain environments, the balance between these two poles could be dynamically and continuously adjusted through time, depending on organizational learning rates (Posen \& Levinthal, 2012). Another tension that could be characterized as a trade-off is the one between cooperation and competition: both poles are always present - competition relates to increasing the organization's market share, while cooperation refers to increasing the size of the market itself (Brandenburger \& Nablebuff, 1995). For a trade-off, although the poles of a tension have an opposing relationship, both poles can be present at the same time, and the challenge is to finetune the partial fulfillment of each pole.

Associating a tension with the notion of puzzle (DeWit \& Meyer, 2010) conveys the idea that management faces a challenging problem with a finite number of defined (but not necessarily known) optimal solutions. It can be said, then, that organizational navigation through stable, low uncertainty, merciful environments could benefit from the puzzle concept: organizations may be able to survive for a long, indefinite amount of time by applying a single solution: establishing itself on a specialized niche or efficiently exploiting their initial success platform.

When characterized as a dilemma, the relationship between different poles in a tension implies that one handles a vexing problem with two possible solutions, neither of which is logically the best (DeWit \& Meyer, 2010), nor does each competing alternative exhibit clear advantages and disadvantages. Dealing with tensions as a dilemma may be useful over the short-term. For instance, in face of low environmental munificence, as in the case of a financial crisis, the organization may be compelled to focus on command and control modes of organizing in order to maximize its survival chances. Conversely, in the course of major technological breakthrough periods, organizations may organize with more autonomy, in order to foster growth opportunities and ensure that the organization is not locked-out of new technologies or technological platforms. Another example of a dilemma is 
associated with the top management team's role: it either optimizes shareholder value, or it strives for the balanced satisfaction of multiple stakeholders (Doyle, 1994).

Finally, conceptualizing a tension as paradox implies that two apparently contradictory or mutually exclusive elements seem to be true at the same time. As such, a paradox would have no real solution, that is, integrating the two opposites into an internally consistent understanding of the problem is precluded. As opposed to the either-or nature of the dilemma, the paradox can be characterized as a both-and problem: one factor is true and the other factor is simultaneously true at the same time (Cameron, 1986; DeWit \& Meyer, 2010; Smith \& Lewis, 2011). At best, decision makers can conceive of a workable reconciliation to cope with the unsolvable paradox. Several strategic situations encompass a paradox, such as the ones relating to the dynamics of commitment and path dependence (Ghemawat, 1991; Sydow, Schreyogg, \& Koch, 2009). In such cases, the decision makers may have to accept that not all strategic options are available to them (because they are locked in a specific path), while at the same time they must find adequate solutions to face new and demanding environmental requisites. This type of situation poses a paradox: the optimal solution has to be as much a product of the organization's past history as it is of the new future market demands - a typical situation is the one involving exploration and exploitation.

\section{Distinctive features of the tension at the heart of organizational ambidexterity}

The tension between exploration and exploitation lies at the heart of the organizational ambidexterity construct. The relationship between these two opposite poles has been depicted in the literature (in more or less explicit terms) with notions like tension, trade-off, puzzle, dilemma, and paradox, as illustrated in Table 2. 
Table 2

\section{Multiple Conceptualizations of the Relationship between Exploration and Exploitation at the Core of Organizational Ambidexterity (OA)}

\begin{tabular}{|c|c|c|}
\hline CONCEPT & SELECTED EXAMPLE OF WORKS THAT USE IT & SELECTED EXAMPLE FROM THE OA LITERATURE \\
\hline Tension & $\begin{array}{l}\text { Andriopoulos and Lewis (2009); Chandrasekaran, Linderman and Schoreder } \\
\text { (2012); Chang, Hughes and Hotho (2011); Judge and Blocker (2008); } \\
\text { O’Reilly and Tushman (2008, 2011); Raisch and Birkinshaw (2008); Raisch, } \\
\text { Birkinshaw, Probst and Tushman (2009); Tiwana, (2008) }\end{array}$ & $\begin{array}{l}\text { This is the fundamental tension at the heart of an enterprise's long-run } \\
\text { survival. The basic problem confronting an organization is to engage in } \\
\text { sufficient exploitation to ensure its current viability and, at the same time, } \\
\text { devote enough energy to exploration to ensure its future viability. (O'Reilly } \\
\text { \& Tushman, 2011, p. 1) }\end{array}$ \\
\hline Trade-off & $\begin{array}{l}\text { Ancona, Goodman, Lawrence and Tushman (2001); Andersen and Nielsen, } \\
\text { (2007); Cao, Gedajlovic and Zhang (2009); Chang et al. (2011); Floyd and } \\
\text { Lane (2000); Gibson and Birkinshaw (2004); He and Wong (2004); } \\
\text { Kyriakopoulos and Moorman (2004); Levinthal and March (2003); Simsek, } \\
\text { Heavey, Veiga and Souder (2009) }\end{array}$ & $\begin{array}{l}\text { Exploration and exploitation are fundamentally different logics that create } \\
\text { tensions. They compete for firms' scarce resources, resulting in the need for } \\
\text { firms to manage the trade-offs between the two. (He \& Wong, 2004, p. 481) }\end{array}$ \\
\hline Puzzle & Birkinshaw and Gibson (2004); O’Reilly and Tushman (2004) & $\begin{array}{l}\text { The failure to achieve breakthrough innovations while also making steady } \\
\text { improvements to an existing business is so commonplace- and so } \\
\text { fascinating - that it has become a battleground of management thought. For } \\
\text { decades, scholars have spun theories to explain the puzzle and offered advice } \\
\text { on how to solve it. (O'Reilly \& Tushman, 2004, p. 1) }\end{array}$ \\
\hline Dilemma & $\begin{array}{l}\text { Benner and Tushman (2003); Cao et al. (2009); Chandrasekaran et al. } \\
\text { (2012); Duncan (1976); Luzon and Pasola (2011) }\end{array}$ & $\begin{array}{l}\text { No study has provided a solution to the dilemma of exploration-exploitation } \\
\text { through ambidexterity. (Luzon \& Pasola, 2011, p. 928) }\end{array}$ \\
\hline Paradox & $\begin{array}{l}\text { Andriopoulos and Lewis (2009, 2010); Bierly and Daly, (2007); O’Reilly } \\
\text { and Tushman (2008); Smith and Tushman (2005); Tiwana (2008) }\end{array}$ & $\begin{array}{l}\text { Because the routines, processes, and skills required for exploitation are } \\
\text { fundamentally different than those required for exploration, we label these } \\
\text { paradoxical capabilities as ambidexterity. (O’Reilly \& Tushamn, 2008, p. } \\
\text { 188). }\end{array}$ \\
\hline
\end{tabular}


Such multiplicity, however, does not seem to be connected with different theoretical standpoints, but rather with authors' stylistic efforts to avoid word repetition. On the other hand, the scrutinizing of topics like organizing for ambidexterity requires a solid conceptual understanding of the relationship between its two main constituents: exploration and exploitation. It can be expected that different conceptualizations will imply different organizing forms; i.e. different perspectives about the tension will lead to different managerial and organizational design choices concerning the pursuit of ambidexterity.

Three main features distinguish the exploration-exploitation relationship that lies at the core of the construct of organizational ambidexterity. First, both of its poles are equally relevant. Organizational focus on exploration will probably improve the firm's profitability in the short run, while it will put the firm's relevance at risk over the long-term. However, favoring exploration to the detriment of exploitation, too much experimentation and uncertainty will likely affect firm profitability, putting the continued existence of the organization at risk in the short-term. Hence, both sides of the tension are equally relevant for ambidexterity.

Second, the relationship between exploration and exploitation includes both opposition and complementarity. On one hand, there is significant opposition between exploration and exploitation, which may require opposing mindsets (Sarasvathy, 2009). Since exploitation and exploration refer to such disparate types of activities, integrating them gives rise to practical issues in connection with resource allocation processes (Christensen, 2011; Christensen \& Raynor, 2013) and organizational design (Galbraith, 2014).

However, there is also an organic complementarity between exploitation and exploration: exploitation generates more certain and stable profits, which in turn can be put to use as investments on exploratory and uncertain efforts. On the other hand, exploration is required for an organization to generate new profit streams that will be exploited, and as a result, will likely improve the overall chances of the organization's success in the long run.

Third, both poles are equally needed for organizational ambidexterity to fulfill its promise. Activating both of them constitutes a necessary condition for organizational growth and renewal, and ultimately healthy longevity. In order to fulfill the construct's promise of promoting organizational healthy longevity, any given firm should strive to foster both exploration and exploitation throughout time, due to their complementary and opposing natures.

\section{A Paradox-based Conceptualization of Organizational Ambidexterity}

We propose that the paradox notion can contribute key dimensions for a comprehensive typology regarding ways of handling the mutually complementary and mutually opposing polarities, which are inherent in the exploration-exploitation relationship. As such, it can provide a theoretical frame that helps understand how organizations manage to foster ambidexterity across multiple analytical levels (Simsek, 2009). For one, the both-and relationship lies at the core of the construct at the organizationallevel, requiring firms' proficiency in simultaneously handling the exploration and exploitation tension (Andriopoulos \& Lewis, 2009; Benner \& Tushman, 2003; Gupta et al., 2006; Smith \& Tushman, 2005). In addition, paradoxical thinking is suited to situations when no choice can effectively provide a workable solution regarding the tension because both solutions are needed and interwoven (Luscher \& Lewis, 2008).

\section{Paradox-related conceptual elements}

Viewed as an up and coming topic (Clegg, 2002; Eisenhardt, 2000), the investigation of paradox in the organizational literature has been the subject of over 360 studies in the past 20 years (Smith \& 
Lewis, 2011). Dualities and tensions play an important role in organizational change and in theorybuilding about organizations (Cameron, 1986; Seo, Putnam, \& Bartunek, 2004), because they refer to polar opposites that often work against one another. They represent opposing pulls that must be dealt with in order for the organization to enjoy a healthy survival in the long-run. The literature on paradoxes suggests four different types of tactics for managing such tensions: selection, separation, integration and transcendence (Seo et al., 2004).

Selection entails denying the need of both poles of the tension, and thereby selecting one side of the tension over the other. Selection is the most typical way whereby theorists manage contradictions; however, it only produces specialized versions of theories - one that disregards key elements and their interrelationships or that ignores the inherent dynamics of the social systems (Poole \& Van de Ven, 1989). Hence, although selection is a possible tactic, it ignores the very inherent distinction about the exploration and exploitation tension: its opposing and complementary nature.

Separation differs from selection, as it acknowledges that both poles of the tension are needed and equally relevant, but it separates them in terms of levels of analysis, topical domains or temporal processes (Poole \& Van de Ven, 1989). Planned change illustrates temporal separation quite well, as it may allow for moments of participatory change, hence producing time separation between two different types of change (Seo et al., 2004).

Integration typically combines both poles of the tension in two ways - neutralization or forced merger (Seo et al., 2004). Neutralization is similar to compromise or splitting the difference when managing contradiction - it refers to a balance such that both poles are legitimate and both remain unfulfilled in their totality. As an illustrative example associated with organizational change, a middle of the road approach to organizational change would be designing an intervention that is both proactive and reactive, but neither characteristic is fully realized. Alternatively, through forced merger one tries to combine the best of both worlds which more often than not produces a confusing whole.

Transcendence refers to managing dualities through transforming dichotomies into a new perspective or a reformulated whole. Transcendence results from change that occurs when dualities are transcended, and the original tension that once existed disappears because of a new conceptual definition or an alternative point of view. Similar to the first approach (selection), transcendence does not aim at providing a workable balance between the opposing poles of a tension.

\section{The paradox-ambidexterity connection}

Paradox resolution tactics and common traps associated with the implementation of those tactics constitute a distinctive feature in the study of paradox (Seo et al., 2004). We propose that organizational ambidexterity can be fostered and sustained through two necessary conditions:

1. the utilization of paradox-coping tactics of separation and integration

2. avoidance of specific paradox-related traps

The tactics of separation and integration were chosen because those are the two that inherently deal with the opposing and complementary duality of the tension between exploration and exploitation. Individually they are unable to cope with the paradox, however their combination is promising.

Our contention is that the purposeful and effective use of both conditions at consecutive organizational levels creates the necessary conditions for ambidexterity to emerge as an organizational property. Hence, by employing space separation at the business unit level, integration must follow at the corporate level. When only one type of tactic is applied in the absence of the other, common paradoxrelated traps occur, precluding ambidexterity to emerge.

Moreover, the existence of both necessary conditions asserts that ambidexterity is not only fostered by the continually pursuance of alternative ways to handle tensions derived from the 
combination of exploration and exploitation, but also from avoiding pitfalls that exist because of the opposition that arises from this combination. This notion is in line with the literature as it offers a dynamic conceptualization of organizational ambidexterity: it is not a steady state capability, but a dynamic one (O'Reilly \& Tushman, 2008) that must be harnessed continually through time by the use of both complementary features.

\section{Fostering ambidexterity through the use of separation tactics}

Handling the exploration-exploitation relationship requires the separation of the opposing poles through architectural ambidexterity (Andriopoulos \& Lewis, 2009; Birkinshaw \& Gibson, 2004; Gupta et al., 2006). This tactic refers to the use of dual structures and strategies, in order to set apart those efforts focused on exploration and exploitation. As noted by Puranam, Singh and Zollo (2006), separation tactics rely on spatial (i.e. dual organizational structures) and/or temporal separation (i.e. periodical oscillation between exploration and exploitation).

With respect to temporal separation, the same set of resources carries out exploration or exploitation at different time-periods. This goes in line with Simsek et al. (2009), who have suggested a way of working around the relationship: by introducing cyclical foci on exploration and exploitation into the organization. In a similar way, ambidexterity may be fostered through sequential attention to goals or rhythmic pacing of tasks. However, this practice requires managerial foresight to identify when to change from exploration into exploitation, and vice-versa. Empirical results have been ambiguous regarding the possibility of establishing when and how one should change from one pole of the tension to the other (Fang \& Levinthal, 2009; Posen \& Levinthal, 2012).

Spatial separation, in turn, enables simultaneous exploration and exploitation activities in the organization. This is often called architectural or structural ambidexterity. A typical example of this tactic would be rendering a core business unit responsible for creating and capturing value from existing products and markets, while another new or existing business unit would be in charge of prospecting new markets and developing new technologies (Birkinshaw \& Gibson, 2004). Sometimes separation is also achieved through the use of a portfolio approach that enables management to draw clear boundaries concerning exploration and exploitation activities. Also, the implementation of spatial separation seems to require resource allocation metrics tailored to the nature of exploration and exploitation activities: while goal-centric metrics fit exploitative efforts, discovery-driven metrics suit exploratory efforts, which tend to focus on learning (McGrath, 2010; McGrath \& Macmillan, 2009; O'Reilly \& Tushman, 2008).

\section{Fostering ambidexterity through the use of integration tactics}

Integration tactics are typically associated with behavioral aspects of management teams, which may integrate both poles of the exploration/exploitation relationship, and produce contextual ambidexterity by making use of specific actions, values or judgment (Andriopoulos \& Lewis, 2009; Birkinshaw \& Gibson, 2004; Gupta et al., 2006). Integration tactics emphasize behavioral and social ways of integrating exploitation and exploration. The basic idea here is that socialization, human resource and team-building practices, foster shared-values and aid coordination, helping actors think and act ambidextrously on a daily basis. This approach is associated with the upper echelons perspective and the top management level. It may be translated as behavioral integration, where the top management team synchronizes their subordinates' social and task processes (Hambrick, 1994), helping executives cope with the contradictory knowledge requirements of exploration and exploitation (Andriopoulos \& Lewis, 2009; Lubatkin et al., 2006). Hence, supportive social processes (i.e. recognition practices, socialization), culture and interpersonal relations may help individuals think and act ambidextrously (Birkinshaw \& Gibson, 2004; Smith \& Tushman, 2005). 


\section{Fostering ambidexterity through the avoidance of paradox-associated traps}

Many researchers have referred to traps that occur through efforts of working around the tensions using the above-mentioned necessary conditions. These traps can be viewed as breakdowns or side effects of the misuse of tactics themselves, which may trigger vicious cycles that lead to an increasingly one-sided focus on either exploitation or exploration. Hence, the emergence of ambidexterity as an organizational property entails not only the continued effort to foster paradox-coping tactics, but also to avoid paradox-related traps.

One-sided emphasis on exploitation or exploration may yield two generic traps, known as the competency and failure traps. An excessive focus on exploitation may engender competency traps (Andriopoulos \& Lewis, 2009; Gupta et al., 2006), meaning that leveraging current capabilities may enable immediate profits, and hence lock in the organization on a given path of success. However, this path may be rendered obsolete at a given point in time, by market or technological changes, and by the time it happens the over-emphasis on exploitation may have produced stagnation or simply weeded the possibility of pursuing other strategic options through mechanisms of path dependence. Similarly, researchers have signaled the existence of failure traps. These happen when organizations gravitate toward exploration. Firms that narrowly seek this end of the tension normally engage in escalating risks, failing to acknowledge past innovation failures. Future opportunities are sought at the expense of today's operations (Andriopoulos \& Lewis, 2009; Gupta et al., 2006).

Another possible paradox-related trap is isolation and lack of coordination between activities (Gibson \& Birkinshaw, 2004). Overusing separation in the absence of the associated integration tactic may lead to the isolation of units, teams or people, ingraining a preferred innovation mode (either continuous or radical), precluding coordination or synergy between efforts.

Another trap to be avoided has been described in the literature as cognitive tug-of-war. It deals with the fact that if exploration and exploitation represent different demands, requiring differing knowledge sets and differing skills, when they are imposed on the same individual they may cause distress, cognitive confusion, and unclear prioritization. This trap may hence hinder the resolution of the essential tension. For instance, Sheremata (2000) describes the need for innovation as a tug of war between centripetal and centrifugal forces. Other authors, such as Gibson and Birkinshaw (2004), remark that integration tactics, commonly associated with top managers, may generate a cognitive tugof-war because this tactic may strain actors, given the complexity and potential confusion posed by the contradictory modes of thinking and acting demanded by the two poles of the paradox.

Finally, the erosion effect refers to behavioral aspects found in integration tactics and describes situations where top management is able to be ambidextrous, but this capability does not reach middle and lower levels of the organization (thus eroding as we proceed downwards the organizational hierarchy). This effect was noted by Birkinshaw and Gibson (2004) and was assumed to be primarily a measure of the consistency and quality of communication on the organization. However, it may also be related to the fact that thinking and acting ambidextrously requires a strategic vision, which is a characteristic of top management, but that may not be present at all organizational levels.

\section{Towards a paradox-based typology of ambidexterity-related organizational states}

Building on the two basic necessary conditions of separation and integration, a comprehensive typology of four possible organizational states can be identified. Viewing an organizational state as a particular configuration of the organizational properties at a certain point in time (Bunge, 1996), each state arises from the presence and/or absence of separation and integration tactics.

With respect to organizing for ambidexterity, each state features distinct strengths and challenges, as these respectively refer to the ability of the organization to effectively foster paradox-coping tactics and avoid paradox-related traps. The specific dynamics of the proposed typology are shown in more detail in Figure 1. 


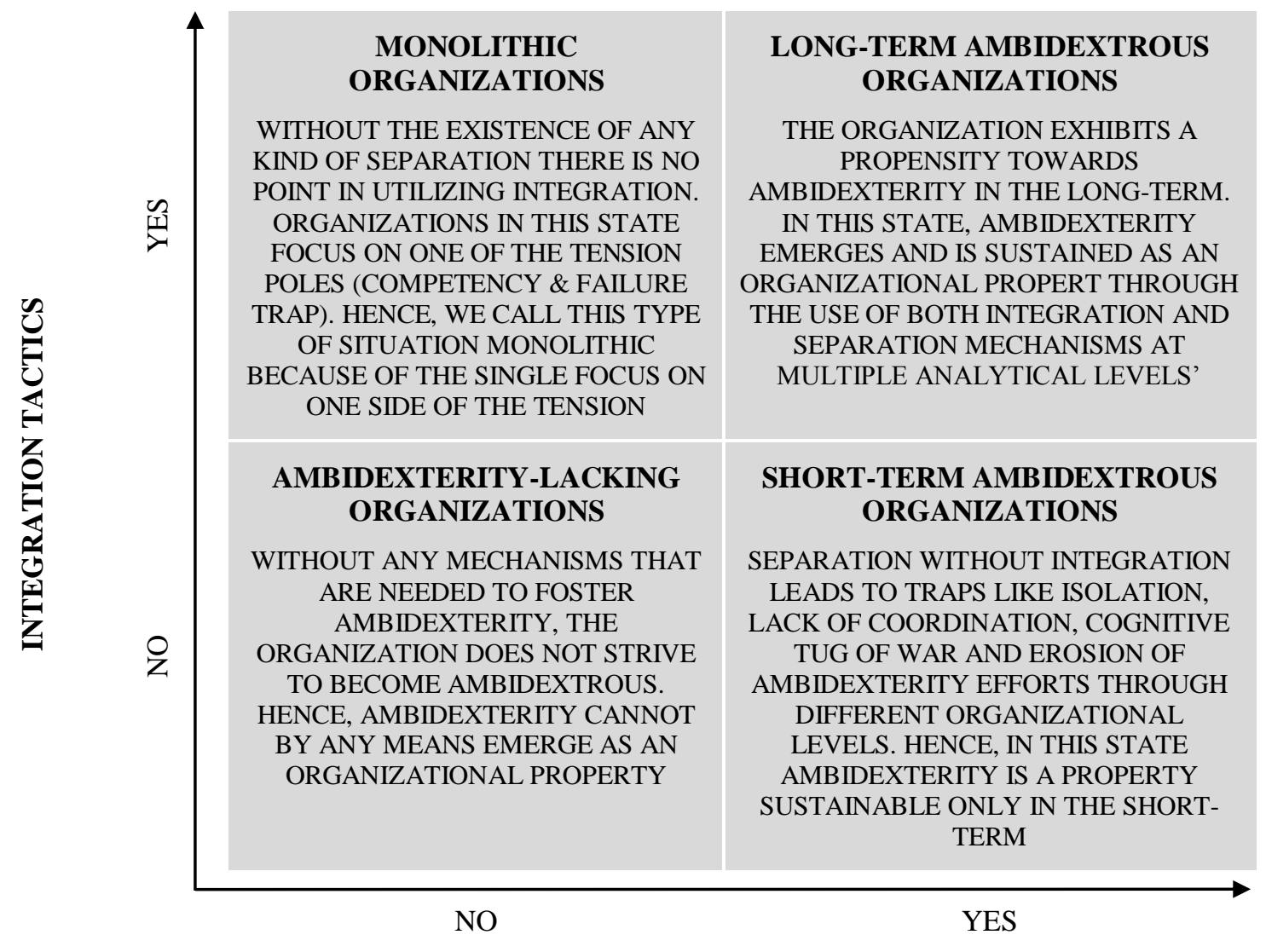

\section{SEPARATION TACTICS}

Figure 1. A Paradox Based Typology of Organizational States Related to Ambidexterity

In the upper-left corner, the absence of separation tactics may lead the organization to focus on one of the tension poles (either exploration or exploitation), which may give rise to the development of competency and failure traps. By emphasizing either exploration or exploitation, the organization becomes monolithic, and because it does not address the paradoxical aspect of the relationship between exploration and exploitation, ambidexterity fails to emerge as an organizational property. This state refers to what we call monolithic organizations.

Regarding the lower-right corner, separation without integration may foster ambidexterity in the short term, but over the long run the lack of integrative tactics may stimulate not only isolation traps (either cultural or practical), but also cognitive tugs-of-war between the parties associated with each pole as well as erosion of ambidexterity efforts through different organizational levels. Hence, in this organizational state, ambidexterity may arise as an organizational property, which it is unlikely to be sustained in the long run. This state corresponds with what we call short-term ambidextrous organizations. Even though separation tactics may foster ambidexterity in the short term, the lack of integration tactics will likely hinder the organization in the long run because it fails to reconcile the exploration-exploitation poles.

The lower-left corner depicts the ambidexterity-lacking organizations, because both conditions are lacking, hindering the possibility of ambidexterity to emerge as an organizational property. The absence of both tactics leaves the organization without the necessary means to pursue ambidexterity in practice.

Finally, the upper-right quadrant is characterized by the presence of both integration and separation tactics. This organizational state includes not only a propensity for ambidexterity to emerge as an organizational property, but for this property to be sustained in the long run. This state concerns what we call long-term ambidextrous organizations. Ambidexterity emerges because both integration and separation tactics are employed to address the complementary and opposing nature of the 
exploration and exploitation relationship. Moreover, the fulfillment of both conditions not only allows ambidexterity to emerge as an organizational property, but it also creates a solid foundation for this property to remain active in the long run, despite the opposing nature of exploration and exploitations. These conditions must be fulfilled at multiple analytical levels, in order to avoid paradox-related traps. The combination of the two necessary conditions at multiple-analytical levels helps coping with the paradox-like relationship between exploration and exploitation, and thus the organization may sustain its ambidextrous property through time.

\section{Implications for Research and Practice}

\section{Implications for further academic research}

We advance three distinct suggestions for further research based on the typology of organizational ambidexterity-related states.

The first possible research avenue is associated with ambidexterity as a process. The proposed contributes a starting point for investigating how organizations may become ambidextrous over time. For instance, what specific processes and mechanisms will likely lead to each identified state? Are there transition processes between states and do they happen? Addressing those questions effectively calls for process-based, longitudinal research on organizational ambidexterity (Burgelman, 2011; Cao et al., 2009).

The second research avenue is associated with ambidexterity as practice. Since organizing for ambidexterity is a key issue in advancing our understanding of how organizations may become ambidextrous over time, there is an opportunity to investigate the micro-practices that constitute foundations of what organizations should do to become ambidextrous. This line of research may develop strong ties with the Strategy as Practice perspective which investigates what people do in relation to strategy and how this is influenced by and influences their organizational and institutional context (Johnson, Langley, Melin, \& Whittington, 2007). Hence, further studies could explore the role of the dyadic conditions of separation and integration in more detail. In what situations do these necessary conditions work well together? Is it possible to unveil best practices for them? How does the application of such conditions differ in different domains and contingencies? Case studies on different types of organizations and different types of sectors could enrich our understanding of which practices contribute most to fostering ambidexterity in different organizational settings.

The third research avenue relates to ambidexterity as the condition for long-term success and healthy longevity. Ambidexterity is a construct that emerges through the interplay of a series of conditions disposed at multiple levels. Hence, there is an opportunity to investigate how multiple analytical levels help to address organizational healthy longevity challenges (Fleck, 2009). Therefore, field studies should search for explanatory variables on all levels: at the individual level (i.e. incentive structures, different leadership personalities), at the organizational level (i.e. organizational design, culture, coalitions) and at the environmental level (i.e. types of inter-firm linkages, strategies for navigating in the institutional environment). The analysis of multiple levels also has the potential to contribute to the scholarly conversation in different research streams, such as cognitive studies and behavioral organization (individual level), resource based view (organizational level) and population ecology and I/O economics (industry-level). 


\section{Implications for practicing managers}

The proposed typology for organizing for ambidexterity provides a blueprint for practicing managers struggling to foster and sustain ambidexterity in their organization. Such managers may benefit from management literature on specific tactics to deal with paradoxical phenomena in organizations, and build their organization's own toolkit for doing so. For instance, an ambidextrous approach to human resource management would call for striking a balance between short and long-term incentives for its employees. Likewise, an ambidextrous approach to a firm's product portfolio would encompass promoting quality control practices in a production line, while at the same time providing incentives for new product ideas to be brought to manager's attention. Hence, by seeking insights in various disciplines and management fields, collecting identified practices, and implementing them with the right mindset, management may help foster organizational ambidexterity in their firms.

Although our typology provides an initial blueprint, there seems to be no sure-fire recipe or silver bullet for building ambidextrous organizations. Becoming ambidextrous is a context-dependent process, which should be aligned with the organization's particular history and culture. It also acknowledges that managers should look for ways to implement the necessary conditions of separation and integration that lay the seed of organizational ambidexterity. Hence ambidexterity should be a guiding construct ever present in a manager's mindset while s/he muddles through the organization's major resource allocation processes (i.e. budgeting, strategic planning, project portfolio planning), and when designing control systems for the organization (i.e. such as performance dashboards, scorecards and even payment incentives). The key to building ambidextrous organizations is not only context-dependent but also continuous search-dependent, a behavior that must be pursued through time.

\section{Conclusions and Limitations}

Aiming at contributing understanding on how organizations become ambidextrous over time, we have scrutinized the nature of the ambidexterity construct, identified two requirements for organizations to become ambidextrous, and explored issues related to organizing for ambidexterity. We propose two necessary conditions for developing ambidexterity: fostering paradox-coping tactics as well as precluding paradox-related traps. The interplay of these two conditions gives rise to a typology of four ambidexterity-related states, entailing distinct organizing features.

This overall rationale sheds light in the fact that organizational ambidexterity has as much to do with organizing as it has with strategizing. Ambidexterity is relevant to achieving healthy longevity in the long run, because the relationship between exploration and exploitation mirrors several challenges associated with it: short-term vs long term, profitability and sustainability, among others. However, while organizational ambidexterity can be deemed relevant to every organization, addressing the challenge of becoming ambidextrous is difficult, contingent upon each organization's characteristics. The typology proposed in this paper constitutes but a first step in providing a comprehensive understanding of what is required for firms to organize for ambidexterity.

Hence, further investigations are required to explore how organizations may become ambidextrous over time as well as how can firms organize for ambidexterity. As the word organizing suggests, research focus should stress the continuous processes involved in moving towards and along strategies and forms, rather than on organizational forms. This perspective also strengthens the view that organizing and strategizing have to be treated not as two discrete practices, but as inextricably linked together, a single duality rather than two separate building blocks (Whittington \& Melin, 2003). Therefore, although the exploration and exploitation tension presents itself as a strategic issue, solving it requires both strategizing and organizing. 


\section{Acknowledgments}

We are grateful for comments and suggestions on an earlier draft provided by Adriano Proença, Carlos Denner, Susan Hill and 2 anonymous reviewers at the EURAM 2014 Conference. The research reported in this paper was partially funded by the CNPq.

\section{References}

Aldrich, H., \& Ruef, M. (1999). Organizations evolving. London: Sage Publications Ltd.

Ancona, D., Goodman, P., Lawrence, B., \& Tushman, M. (2001). Introduction to special topic forum on time and organizational research. Academy of Management Review, 26(4), 507-511. doi: 10.5465/AMR.2001.5393884

Andersen, T., \& Nielsen, B. (2007). The effective ambidextrous organization: a model of integrative strategy making processes [Working Paper $\mathrm{n}^{\circ}$ 12/2007]. Copenhagen Business School, Copenhagen, Denmark.

Andriopoulos, C., \& Lewis, M. W. (2009). Exploitation-exploration tensions and organizational ambidexterity: managing paradoxes of innovation. Organization Science, 20(4), 696-717. doi: 10.1287/orsc. 1080.0406

Andriopoulos, C., \& Lewis, M. W. (2010). Managing innovation paradoxes: ambidexterity lessons from leading product design companies. Long Range Planning, 43(1), 104-122. doi: 10.1016/j.lrp.2009.08.003

Barney, J. (1991). Firm resources and sustained competitive advantage. Journal of Management, 17(1), 99-120. doi: 10.1177/014920639101700108

Benner, M. J., \& Tushman, M. (2003). Process management and technological innovation: a longitudinal study of the photography and paint industries. Administrative Science Quarterly, 47(4), 676-706. doi: 10.2307/3094913

Bierly, P. E., \& Daly, P. S. (2007). Alternative knowledge strategies, competitive environment, an organizational performance in small manufacturing firms. Entrepreneurship Theory and Practice, 31(4), 493-516. doi: 10.1111/j.1540-6520.2007.00185.x

Birkinshaw, J., \& Gibson, C. (2004). Building ambidexterity into an organization. MIT Sloan Management Review, 45(4), 47-55.

Brandenburger, A., \& Nablebuff, B. (1995, July). The right game: the use of game theory to shape strategy. Harvard Business Review. Retrieved from https://hbr.org/1995/07/the-right-game-usegame-theory-to-shape-strategy

Bunge, M. (1996). Finding philosophy in social science. New Haven: Yale University Press.

Burgelman, R. A. (2011). Bridging history and reductionism: a key role for longitudinal qualitative research. Journal of International Business Studies, 42(5), 591-601. doi: 10.1057/jibs.2011.12

Cameron, K. S. (1986). Effectiveness as a paradox: consensus and conflict in conceptions of organizational effectiveness. Management Science, 32(5), 539-553. doi: 10.1287/mnsc.32.5.539

Cao, Q., Gedajlovic, E., \& Zhang, H. (2009). Unpacking organizational ambidexterity: dimensions, contingencies, and synergistic effects. Organization Science, 20(4), 781-796. doi: 10.1287/orsc. 1090.0426 
Chandrasekaran, A., Linderman, K., \& Schroeder, R. (2012). Antecedents to ambidexterity competency in high technology organizations. Journal of Operations Management, 30(1/2), 134-151. doi: 10.1016/j.jom.2011.10.002

Chang, Y., Hughes, M., \& Hotho, S. (2011). Internal and external antecedents of SMEs' innovation ambidexterity outcomes. Management Decision, 49(10), 1658-1676. doi: $10.1108 / 00251741111183816$

Christensen, C. (2011). The innovator's dilemma: when new technologies cause great firms to fail. Boston: Harvard Business Review Press.

Christensen, C., \& Raynor, M. (2013). The innovator's solution: creating and sustaining successful growth. Boston: Harvard Business Review Press.

Clegg, S. R. (2002). General introduction. In S. R. Clegg (Ed.), Management and organization paradoxes (pp. 1-8, Advances in Organization Studies 9). Amsterdam: John Benjamins. doi: 10.1075/aios.9.02cle

Coad, A. (2009). The growth of firms: a survey of theories and empirical evidence (New perspectives on the modern corporation). Massachusetts: Edward Elgar Publishing.

Coad, A., \& Tamvada, J. P. (2008). The growth and decline of small firms in developing countries [Papers on Economic Evolution 2008-08]. Max Plack Institute of Economics, Evolutionary Economics Group, Germany.

DeWit, B., \& Meyer, R. (2010). Strategy: process, content, context - an international perspective. Boston: Cengage Learning.

DiMaggio, P., \& Powell, W. (1983). The iron cage revisited: institutional isomorphism and collective rationality in organizational fields. American Sociological Review, 48(2), 147-160.

Dougherty, D., \& Hardy, C. (1996). Sustained product innovation in large, mature organizations: overcomming innovation-to-organization problems. Academy of Management Journal, 39(5), 1120-1153. doi: 10.2307/256994

Doyle, P. (1994). Setting business objectives and measuring performance. Journal of General Management, 20(2), 1-19. doi: 10.1016/0263-2373(94)90002-7

Duncan, R. (1976). The ambidextrous organization: designing dual structures for innovation. In R. Kilaman \& L. Pondy (Eds.), The management of organizational design (pp. 167-188). New York: North Holland.

Eisenhardt, K. M. (2000). Paradox, spirals, ambivalence: the new language of change and pluralism. Academy of Management Review, 25(4), 703-706. doi: 10.5465/AMR.2000.3707694

Fang, C., \& Levinthal, D. (2009). Near-term liability of exploitation: exploration and exploitation in multi-stage problems. Organization Science, 20(3), 538-551. doi: 10.1287/orsc.1080.0376

Feser, C. (2012). Serial innovators: firms that change the world. New Jersey: John Wiley Sons.

Fleck, D. (2009). Archetypes of organizational success and failure. Brazilian Administrative Review, 6(2), 78-100. Retrieved from http://www.scielo.br/pdf/bar/v6n2/v6n2a02.pdf. doi: $10.1590 / \mathrm{S} 1807-76922009000200002$

Floyd, S. W., \& Lane, P. J. (2000). Strategizing throughout the organization: managing role conflict in strategic renewal. Academy of Management Review, 25(1), 154-177. doi: 10.5465/AMR.2000.2791608 
Galbraith, J. (2014). Designing organizations: strategy, structure, and process at the business unit and enterprise levels. New Jersey: John Wiley Sons.

Ghemawat, P. (1991). Commitment: the dynamics of strategy. New York: Free Press.

Gibson, C. B., \& Birkinshaw, J. (2004). The antecedents, consequences, and mediating role of organizational ambidexterity. Academy of Management Journal, 47(2), 209-226. doi: $10.2307 / 20159573$

Gupta, A. K., Smith, K. G., \& Shalley, C. E. (2006). The interplay between exploration and exploitation. Academy of Management Journal, 49(4), 693-706. doi: 10.5465/AMJ.2006.22083026

Hambrick, D. C. (1994). Top management groups: a conceptual integration and reconsideration of the "team" label. Research in Organizational Behavior, 16, 171-213.

He, Z.-L., \& Wong, P.-K. (2004). Exploration vs exploitation: an empirical test of the ambidexterity hypothesis. Organization Science, 15(4), 481-494. doi: 10.1287/orsc.1040.0078

Johnson, G., Langley, A., Melin, L., \& Whittington, R. (2007). Strategy as practice: research directions and resources. Cambridge: Cambridge University Press.

Judge, W. Q., \& Blocker, C. P. (2008). Organizational capacity for change and strategic ambidexterity. European Journal of Marketing, 42(9-10), 915-926. doi: 10.1108/03090560810891073

Kyriakopoulos, K., \& Moorman, C. (2004). Tradeoffs in marketing exploitation and exploration strategies: the overlooked role of market orientation. International Research in Marketing, 21, 219-240. Retrieved from https://faculty.fuqua.duke.edu/ moorman/Publications/IJRM2004.pdf. doi: 10.1016/j.ijresmar.2004.01.001

Levinthal, D. A., \& March, J. G. (1993). The myopia of learning [Special Issue]. Strategic Management Journal, 14(S2), 95-112. doi: 10.1002/smj.4250141009

Lubatkin, M. H., Simsek, Z., Ling, Y., \& Veiga, J. F. (2006). Ambidexterity and performance in smallto-medium-sized firms: the pivotal role of top management team behavioral integration. Journal of Management, 32(5), 646-672. doi: 10.1177/0149206306290712

Luscher, L. S., \& Lewis, M. W. (2008). Organizational change and managerial sensemaking: working through paradox. Academy of Management Journal, 51(2), 221-240. doi: 10.5465/AMJ.2008.31767217

Luzon, M. D. M., \& Pasola, J. V. (2011). Ambidexterity and total quality management: towards a research agenda. Management Decision, 49(6), 927-947. doi: 10.1108/00251741111143612

March, J. G. (1991). Exploration and exploitation in organizational learning. Organization Science, 2(1), 71-87. doi: $10.1287 /$ orsc. 2.1 .71

McGrath, R., \& McMillan, I. (2009). Discovery-driven growth: a breakthrough process to reduce risk and seize opportunity. Boston: Harvard Business Press.

McGrath, R. G. (2010). Business models: a discovery driven approach. Long Range Planning, 43(2/3), 247-261. doi: 10.1016/j.lrp.2009.07.005

Mintzberg, H., \& Waters, J. A. (1985). Of strategies, deliberate and emergent. Strategic Management Journal, 6(3), 257-272. doi: 10.1002/smj.4250060306

O'Reilly, C. A., III, Harreld, J. B., \& Tushman, M. L. (2009). Organizational ambidexterity: IBM and emerging business opportunities. California Management Review, 51(4), 75-99. doi: $10.2139 /$ ssrn. 1418194 
O'Reilly, C., III, \& Tushman, M. (2004). The ambidextrous organization. Harvard Business Review, 82(4), 74-81. Retrieved from https://hbr.org/2004/04/the-ambidextrous-organization

O'Reilly, C. A., III, \& Tushman, M. L. (2008). Ambidexterity as a dynamic capability: resolving the innovator's dilemma. Research in Organizational Behavior, 28, 185-206. doi: 10.1016/j.riob.2008.06.002

O’Reilly, C. A., III, \& Tushman, M. L. (2011). Organizational ambidexterity in action: how managers explore and exploit. California Management Review, 53(4), 5-22. doi: 10.1525/cmr.2011.53.4.5

Peteraf, M. (2003). The cornerstones of competitive advantage: a resource based view. In N. J. Foss (Ed.), Resource, firms and strategy (pp. 187-204). Oxford: Oxford Management Readers.

Posen, H. E., \& Levinthal, D. A. (2012). Chasing a moving target: exploitation and exploration in dynamic environments. Management Science, 58(3), 587-601. doi: 10.1287/mnsc.1110.1420

Poole, M. S., \& Van de Ven, A. H. (1989). Using paradox to building management and organizational theories. Academy of Management Review, 14(4), 562-578. doi: 10.5465/AMR.1989.4308389

Priem, R. L., \& Butler, J. E. (2001). Is the resource-based view a useful perspective for strategic management research? Academy of Management Review, 26(1), 22-40. doi: 10.5465/AMR.2001.4011928

Puranam, P., Singh, H., \& Zollo, M. (2006). Organizing for innovation: managing the coordination autonomy dilemma in technology acquisitions. Academy of Management Journal, 49(2), 263280. doi: 10.5465/AMJ.2006.20786062

Raisch, S., \& Birkinshaw, J. (2008). Organizational ambidexterity: antecedents, outcomes, and moderators. Journal of Management, 34(3), 375-409. doi: 10.1177/0149206308316058

Raisch, S., Birkinshaw, J., Probst, G., \& Tushman, M. L. (2009). Organizational ambidexterity: balancing exploitation and exploration for sustained performance. Organization Science, 20(4), 685-695. doi: 10.1287/orsc. 1090.0428

Sarasvathy, S. (2009). Effectuation: element of entrepreneurial expertise (New horizons in entrepreneurship series). London: Edward Elgar Publishing.

Seo, M.-G., Putnam, L. L., \& Bartunek, J. M. (2004). Dualities and tensions of planned organizational change. In M. S. Poole \& Van de Ven, A. H. (Eds.), Handbook of organizational change and innovation (pp. 73-106). Oxford: Oxford University Press.

Sheremata, W. A. (2000). Centrifugal and centripetal forces in radical new product development under time pressure. Academy of Management Review, 25(2), 389-408. doi: 10.5465/AMR.2000.3312925

Simonetti, R. (1996). Technical change and firm growth: creative destruction in the fortune list, 196387. In E. Helmstadter \& M. Perlman (Eds.), Behavioral norms, technological progress, and economic dynamics (pp. 151-182). (Studies in Schumpeterian Economics). Michigan: Michigan Press.

Simsek, Z. (2009). Organizational ambidexterity: towards a multilevel understanding. Journal of Management Studies, 46(4), 597-624. doi: 10.1111/j.1467-6486.2009.00828.x

Simsek, Z., Heavey, C., Veiga, J. F., \& Souder, D. (2009). A typology for aligning organizational ambidexterity's conceptualizations, antecedents, and outcomes. Journal of Management Studies, 46(5), 864-894. doi: 10.1111/j.1467-6486.2009.00841.x 
Smith, W. K., \& Lewis, M. W. (2011). Toward a theory of paradox: a dynamic equilibrium model of organizing. Academy of Management Review, 36(2), 381-403.

Smith, W. K., \& Tushman, M. L. (2005). Managing strategic contradictions: a top management model for managing innovation streams. Organization Science, 16(5), 522-536. doi: $10.1287 /$ orsc. 1050.0134

Stubart, C. I., \& Knight, M. B. (2006). The case of disappearing firms: empirical evidence and implications. Journal of Organizational Behavior, 27(1), 79-100. doi: 10.1002/job.361

Sydow, J., Schreyogg, G., \& Koch, J. (2009). Organizational path dependence: opening the black box. Academy of Management Review, 34(4), 689-709.

Tiwana, A. (2008). Do bridging ties complement strong ties? An empirical examination of alliance ambidexterity. Strategic Management Journal, 29(3), 251-272. doi: 10.1002/smj.666

Whittington, R., \& Melin, L. (2003). The challenge of organizing/strategizing. In A. M. Pettigrew, R. Whittington, L. Melin, C. Sanchez-Runde, F. A. J. van den Bosch, W. Ruigrok, \& T. Numagami (Eds.), Innovative forms of organizing (pp. 35-48). London: Sage Publications Ltd.

Williamson, O. (1999). Strategy research: governance and competence perspectives. Strategic Management Journal, 20(12), 1087-1110. Retrieved from http://onlinelibrary.wiley.com/doi/10.1002/(SICI)1097-0266(199912)20:12\%3C1087::AIDSMJ71\%3E3.0.CO;2-Z/epdf. doi: 10.1002/(SICI)1097-0266(199912)20:12<1087::AIDSMJ71>3.0.CO;2-Z

Winter, S. (2003). Understanding dynamic capabilities. Strategic Management Journal, 24(10), 991995. Retrieved from http://onlinelibrary.wiley.com/doi/10.1002/smj.318/epdf. doi: 10.1002/smj.318

Zott, C. (2003). Dynamic capabilities and the emergence of intra-industry differential firm performance: insights from a simulation study. Strategic Management Journal, 24(2), 97-125.

\title{
Authors' Profiles
}

\author{
Daniel Karrer \\ Rua Pascoal Lemme, 355, Ilha do Fundão, 21941-918, Rio de Janeiro, RJ, Brazil. E-mail address: \\ daniel.karrer@ coppead.ufrj.br \\ Denise Fleck \\ Rua Pascoal Lemme, 355, Ilha do Fundão, 21941-918, Rio de Janeiro, RJ, Brazil. E-mail address: denise@ coppead.ufrj.br
}

